\title{
SLIT3 wt Allele
}

National Cancer Institute

\section{Source}

National Cancer Institute. SLIT3 wt Allele. NCI Thesaurus. Code C126789.

Human SLIT 3 wild-type allele is located in the vicinity of $5 q 35$ and is approximately $640 \mathrm{~kb}$ in length. This allele, which encodes slit homolog 3 protein, is involved in cell migration. 